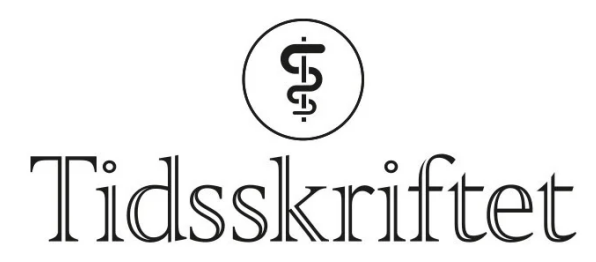

DEN NORSKE LEGEFORENING

\title{
Hvordan snu den negative trenden?
}

\author{
LEGELIVET
}

\section{FREDRIK BÅÅTHE}

fredrik.baathe@lefo.no

Fredrik Bååthe er gjesteforsker ved LEFO - Legeforskningsinstituttet.

\section{De siste ti årene har norske leger rapportert lavere tilfredshet og økte nivåer av stress og utmattelse.}

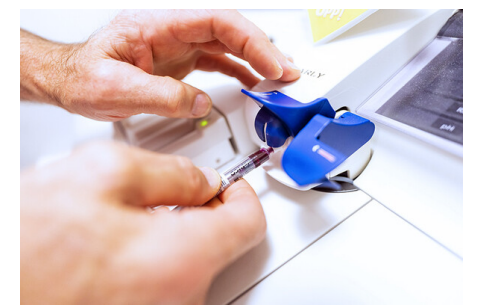

Bilde: Håkon Mosvold Larsen

/ NTB

Den uheldige utviklingen i Norge ser ut til å følge trenden som er vist i internasjonal forskning. Forskere fra Legeforskningsinstituttet og Avdeling for atferdsmedisin ved Universitetet i Oslo har nylig presentert de norske erfaringene (1).

I helsetjenesten er det en innebygget ubalanse der kliniske behov hele tiden må balanseres mot tilgjengelig personell og økonomiske ressurser. Denne spenningen mellom organisatorisk oppmerksomhet på økonomi og legenes vekt på å gi best mulig behandling til den enkelte pasient skaper en risiko for at leger opplever arbeidet som mindre meningsfullt. Risikoen øker dersom legene erfarer at de ikke får anerkjennelse for arbeidet fra ledelsen (2 $)$.

\section{Hva kan gjøres?}

Forskning peker på muligheter til å snu den negative utviklingen til en mer positiv spiral. Fundamentet baseres på et tilsynelatende selvinnlysende perspektiv: Ledelsen må sikre at leger og annet helsepersonell deltar aktivt i arbeidet med å utvikle kliniske prosesser og organisatoriske prinsipper i helsetjenesten. For å lykkes må ledelsen handle i samsvar med de psykologiske og sosiale behovene som er grunnleggende for legers motivasjon og engasjement (3-6) . 
Utmattelse kan motvirkes. Sentrale virkemidler er å involvere leger i klinikknært utviklingsarbeid, anerkjenne deres ideer og som sjef lytte for å avdekke aktuelle vansker (7.). Det trengs en bevisst samarbeidsstruktur der lederne sørger for at leger har dedikert tid til å bidra i denne typen organisatorisk utviklingsarbeid.

Forskningen på feltet kan oppsummeres i tre hovedbudskap (1, s. 108):

Den eneste holdbare måten på lang sikt for å håndtere budsjettmessige dilemmaer er å utvikle de kliniske behandlingsprosessene, det vil si måten medarbeiderne i helsetjenesten samarbeider på for å møte pasientenes behov.

Ledere må aktivt delta i det lokale utviklingsarbeidet for å forbedre behandlingskvaliteten og samtidig bedre arbeidsforholdene.

Ledere må lære seg å se den andres perspektiv slik at man bedre kan samarbeide mot felles mål om stadig å utvikle tjenestene.

\section{LITTERATUR}

1. Rø KI, Rosta J, Tyssen R et al. Doctors well-being, quality of patient care and organizational change: Norwegian experiences. I: Montgomery AJ, Van der Doef M, Panagopoulou E et al, red. Connecting health care worker well-being, patient safety and organizational change: The triple challenge. Cham: Springer, 2020: 91-114.

2. Bailey C, Madden A. What makes work meaningful - or meaningless. MIT Sloan Manag Rev 2016; 57: 53-61.

3. Ryan RM, Deci EL. Self-determination theory and the facilitation of intrinsic motivation, social development, and well-being. Am Psychol 200o; 55: 68-78. [PubMed][CrossRef]

4. Hertzberg TK, Skirbekk H, Tyssen R et al. Den gode legen - sterk og utholdende. Tidsskr Nor Legeforen 2016; 136: 1631-4. [PubMed][CrossRef]

5. Swensen S, Shanafelt T. Mayo Clinic strategies to reduce burnout: 12 actions to create the ideal workplace. Oxford: Oxford University Press, 2020.

6. Bååthe F, Norbäck LE. Engaging physicians in organisational improvement work. J Health Organ Manag 2013; 27: 479-97. [PubMed][CrossRef]

7. Swensen S, Kabcenell A, Shanafelt T. Physician-organization collaboration reduces physician burnout and promotes engagement: the Mayo Clinic experience. J Healthc Manag 2016; 61: 105-27. [PubMed][CrossRef]

Publisert: 8. november 2021. Tidsskr Nor Legeforen. DOI:10.4045/tidsskr.21.0708 (C) Tidsskrift for Den norske legeforening 2023. Lastet ned fra tidsskriftet.no 26. april 2023. 